\title{
地域施設の再編に係る公民館の構成機能と多様性 THE COMPOSITIONAL FUNCTION AND DIVERSITY OF A KOUMINKAN FOR REORGANIZATION OF LOCAL FACILITIES
}

\author{
金 潤 煥*，浅野平八**，広田直行*** \\ Yun-hwan KIM, Heihachi ASANO and Naoyuki HIROTA
}

\begin{abstract}
This paper aims at acquiring the effective knowledge in connection with a defined function of a Kouminkan. A viewpoint is considered on the side of a defined function of the actual condition of the program of a Kouminkan.

The result of analysis, social education facilities and central facilities of an area take up as fundamental character of a Kouminkan. As an element which should be examined for the planning of a Kouminkan, the social education function as a social education facilities, the local self-government function and a community welfare function as a central facilities of an area are raised.
\end{abstract}

Keywords : Kouminkan, local facilities, reorganization, compositional function, element of facilities planning 公民館，地域施設，再編成，構成機能，施設計画要素

\section{1. 問題の提起}

1949 年制定の社会教育法を法的根拠に設置された公民館は, 設置 開始から 50 余年が経過している。社会教育法制定以前の初期公民 館，公民館的施設まで含むと，その歴史は大正，明治，さらに中世 までさかのぼってみられる*1。

また，最新の文部科学省の指定統計である 1999 年度社会教育調 查によると，公民館は全国的に分館を含めて 18, 257 館，類似施設 まで入れると 19,063 館が設置されていて, 社会教育施設の中で最 も多い施設となっている。公民館のつぎに多く設置されている図書 館と比べると, 市町村レベルでの公民館の設置率は $91.7 \%$ で, 図書 館は $49.0 \%$ である。

このように全国に多数ストックされている公民館の機能は, 歴史 的な変遷過程にみられる ‘地域の総合施設*2, としての機能を残し ながら，地域ごとに多様な形態をもって発展してきた。関連法律で 施設の設置目的や事業内容が定められている公民館の役割が地域 によって異なることは，公民館の条件整備，職員体制等が，設置主 体である自治体独自の施策に委任されたからである。

すなわち，社会教育学の小林文人氏が ‘選択的多様化*3” と表現 している地域的多様化が自治体間の格差を生み出している。それは，
公民館制度自体の弱さと基準のあいまいさを端的に示すことでも あり, 地域ごとに異なる社会・人文的環境と地理的環境が反映され ていると考えられる。

また, 1980 年代後半から, 社会教育または生涯学習の体制の再整 備が模索されて，公民館に関わる制度的環境が変化している。生涯 学習振興整備法*1 の制定 (1990) や地方分権・規制緩和策に基づいた 社会教育法の改正（1999）が大きな制度的変化である。さらに，新 設公民館に関わる国庫補助の終了(1997)，国庫補助を受けて建設さ れた公民館の社会教育施設の範囲内での転用の許容 (2001) などが 行われて，現在，公民館は転換期を迎えている。

このような制度的変化にしたがって公民館に対する再認識の問 題が提起されている*5。日本における社会教育施設の中核として役 割を果たしてきた公民館の施設機能を再認識することは, 今後の地 域施設を再構築するためにも必要なことと考える。

なお，公民館の普遍的機能については筆者らの既往研究*6 で明ら かにしているが，公民館の歷史的展開過程と地域的定着過程にみら れる多様性は，今後予想される地域施設再編に有効な先進性を持っ ていると考えられる。したがって，地域施設を包括的に検討し再編 するためには，既設公民館を分析して検討しなければならない。
*日本大学大学院生産工学研究科貄築工学専攻 大学院生.工修

** 日本大学生産工学部建築工学科 教授・工博

*** 日本大学生産工学部建築工学科 尃任講師 ·博士 (工学)
Graduate Student, Dept. of Architectural Engineering, Graduate School of Industrial Technology, Nihon Univ., M. Eng.

Prof., Dept. of Architectural Engineering, College of Industrial Technology, Nihon Univ., Dr. Eng.

Lecturer, Dept. of Architectural Engineering, College of Industrial Technology, Nihon Univ., Dr. Eng. 


\section{2. 研究の目的}

本稿は全国各地公民館の開催事業を比較検討することから公民 館の多様性の実態を明らかにするとともに，多様な実態を認識する ための指標を提示して，地域施設の機能設定に関わる有効な知見を 得ることを目的とする。

公民館における多様性の分析は，歴史的な展開過程，地域的な定 着過程，施設機能の実態など，さまざまな視点でみることができる が*7, 本稿では‘施設計画における思考展開の過程*” の中での機能 設定の側面に観点を置いて, 公民館の施設機能の実態について考察 する。

特に, 施設の設置目的あるいは事業目的を達成するために策定さ れる事業内容, 寸なわち ‘構成機能’ の分析に重点を置く。

\section{3. 研究の方法}

\section{3-1 資料収集の方法}

公民館の施設機能の実態を調べるために本稿では，事業内容が充 実していて活発な活動を行っていると考えられる，全国の優良公民 館*9を対象にアンケート調査を行う。

アンケートは，優良公民館として文部大臣表彰を受けたことのあ る全国の 555 公民館 ${ }^{* 10}$ に対して，2000 年に北海道から近畿地方ま でを調查し，2001 年に山陰地方から九州地方までを調查した。有効 アンケートの回収率"11 は $40.2 \%$ である。

アンケートの調查内容は, 開催事業のほか, 公民館の役割に関す る職員の意識についてである。

開催事業の種類については, 公民館の館内外で行われている公民 館主催事業のほかに，地域施設としての貸し館的な利用も多くみら れることから，事業主体と事業が行われる場所の組み合わせにより， [場所の提供 - 外部組織の開催事業］（以下，アンケート調査で区分 した調查項目のカテゴリーには［］表記），[場所と機会の提供 - 公 民館で行う公民館主催事業]，[機会の提供 - 公民館以外で行う公民 館主催事業]の 3 つのカテゴリーに分けて，開催事業の名称につい ての記入を依頼する。

公民館の役割に関寸る職員の意識については，初期創設期の公民 館にみられる農村の生活全般（産業複興，自治振興，授産；福祉， 社交·娛楽など）にわたる地域の総合的施設としての機能と制度的 な側面にみられる社会教育の尃門機関としての機能に関する二重 性の問題*12 と, 公民館研究の課題として残されている地域福祉と公 民館との関係の問題 ${ }^{* 13}$ とに限定する。このことにより，調査項目は 公民館が本来持っている役割である社会教育，地域自治，地域福祉 を取り上げ，質問項目としては，「教育」、「自治」、「福祉」の中から 回答者が在職する個別の公民館において施設の役割として重要度 が高いと思う順番に番号表記を依頼する。

\section{3-2 資料分析の手順之方法}

アンケートの結果分析は次の手順と方法で行う。

1) 開催事業の分類

アンケート調査から得られた公民館の開催事業を内容によって 分類する。

既存の文部科学省の社会教育調査, 各市町村の社会教育関連統計
または公民館要覧などの資料にみられる公民館主催の講座·学級の 分類項目とその基準を娭討してみると, 分類項目にあいまい性が残 されており，統一性，整合性がなく*14，公民館機能を包括的に明ら かにするためには不充分なため, 本稿では独自の分類項目とその基 準を検討し設定する。

分類の基準項目は，筆者らの既往の研究*8で提示した施設機能分 析の方法論である ‘施設計画における思考展開の過程’において, 施設の目的達成のためゆ事業内容として示される ‘構成機能’に該 当する項目を中心とする。

2）開催事業の全国的実態分析

分類項目ごとに分類された開催事業をアンケートのカテゴリー すなわち [場所の提供]， [場所と機会の提供]，[機会の提供]別に 集計し，回答率"11を求氻る。

求められたカテゴリー別分類項目ごとの回答率の傾向を分析し, 開催事業からみた全国的な公民館の施設機能の実態を考察する。

3）地域別開催事業の実態分析

地域別に公民館の機能を検討するにあたっては, 各地域ごとの事 例数を一定量確保するため, 農林水産省の全国農業地域区分 ${ }^{* 15} に し$ たがって全国を 14 地方*16に分けて集計し，地方別の開催事業の回 答率を求める。

求められた地方別の分類項目ごとの回答率は, 開催事業の項目数 と地方別対象事例数にばらつきがある。比較分析を行うために地方 別回答率を分類項目ごをに基準化 ${ }^{* 17}$ を行い，各地方別の分類項目ご との回答率を同じパラメータ上にする。これを比較分析し, 開催事 業からみた地域別公民館の施設機能の実態を考察する。

4)公民館の役割に関する職員の意識の実態分析

公民館の役割に関する職員の意識に関しては，「教育」、「自治」, 「福祉」の 3 つの質問項目ごとに重要度第 1 位と答えた事例のみを 集計し，「教育」、「自治」、「福祉」の項目ごとの全国回答率と地方 別回答率を求める。求妨られた回答率から，公民館の役割に関する 職員の意識の全国傾向に地方別傾向を検討し，施設管理者側が認識 している公民館の施設像とする。

5)地域施設の再編に倸方施設機能要素の検討

以上で考察した公民館の施設機能の実態に関する分析結果をも とに，公民館の機能設宛に関わる施設計画要素の検討を行う。

\section{4. 開催事㘹の分析による公民館の機能 4-1 内容による開催事莱の分類}

アンケート調査から，[場所の提供]に 45 種類, [場所と機会の提 供］に 153 種類, [機会の提供]に106 種類の開催事業の名称が抽 出できた。その中から 1 事例のみの回答項目を除く, 複数館で開催 されている事業に着目すると, それぞれ 30 種類, 82 種類, 36 種類 の項目に整理できる（表-1）。

表-1から, 公民館の開催事業はその種類が多いことがわかる。ま た, カテゴリ一別に 1 事例のみの回答項目数が全回答項目数の約半 分以上であることは，事業内容が施設ごとに異なっていることを端 的に示している。

調查から得られた表-1 の開催事業名を表-2 のように分類する。 各分類項目の抽出方法と分類基準は次の通りである。 
表-1 カテゴリー別回答項目

\begin{tabular}{|c|c|}
\hline カ & 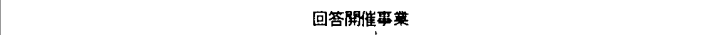 \\
\hline \multirow[t]{2}{*}{ 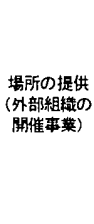 } & 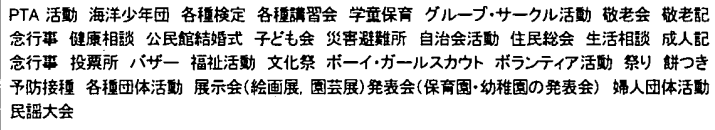 \\
\hline & 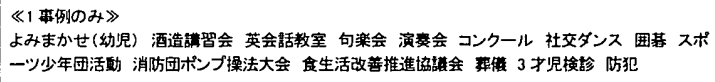 \\
\hline \multirow{2}{*}{ 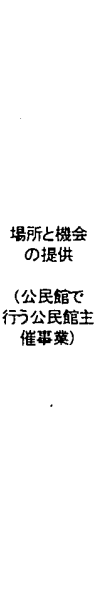 } & 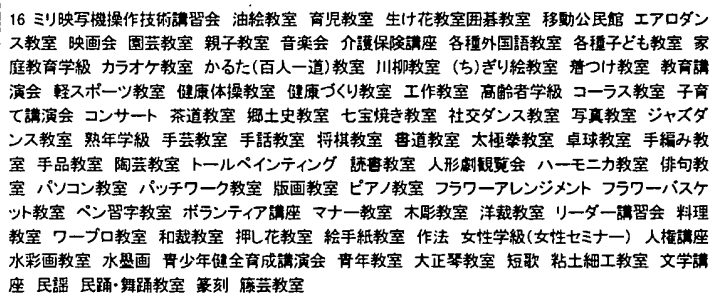 \\
\hline & 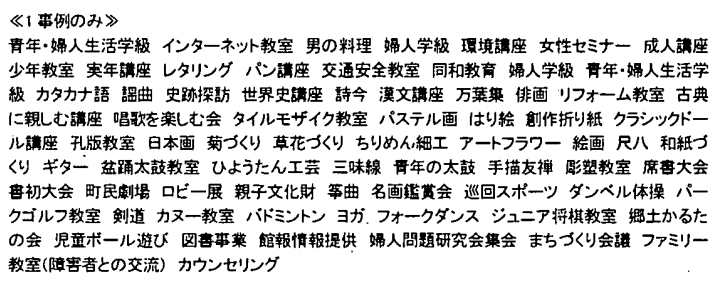 \\
\hline \multirow{2}{*}{ 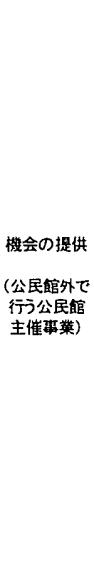 } & 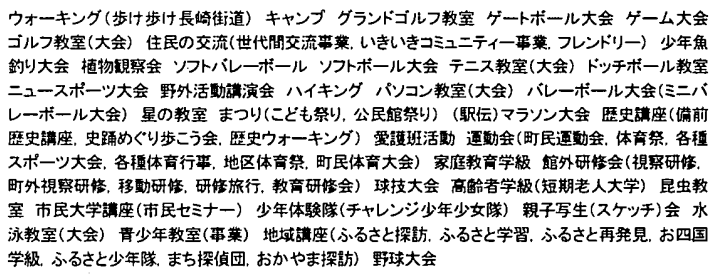 \\
\hline & 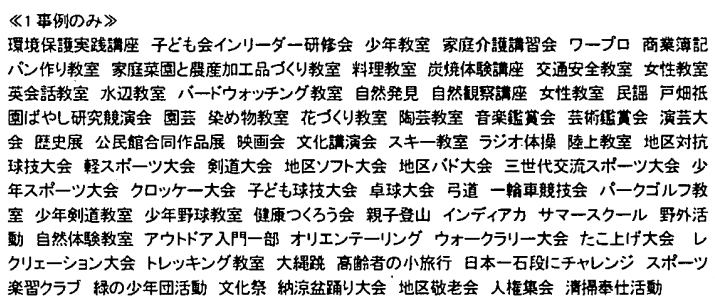 \\
\hline
\end{tabular}

(1)〜(9)の分類項目については, 社会教育法等現行制度上に示され ている 構成機能*1《’ の各項目を用いる。

\{(1)実際生活に即寸る教育\}（以下，表-2の分類項目は＼{＼}表記） は，基本的に衣食住に関連する内容と実用技術，居住地域または環 境に関する内容である。\{(2)学術に関する各種事業\} は，衣食住以 外の学問に関する内容である。\{(3)文化に関する各種事業\} は, 芸 術的, 技術的行為である。\{(4)体育に関する各種集会\}は, 健康で 健全な生活を営む能力の育成に関する内容である。\{(5)レクリエー ションに関する集会\}は，休養や姮楽に関する内容である。\{(6)図 書·資料関連事業\} は，図書，資料，情報提供に関寸る内容である。 \{(7)各種団体・機関等の連絡及び利用\}については, 関連法令から抽 出した項目は '各種団体·機関等の連絡’ であるが, 分類の円滑を はかるために団体・機関等の利用行為も含む。ここで言う団体とは 集団目的が明確である機能的組織集団を示す。会員の集会が主目的 とも言える趣味関連サークル,クラブなどの基礎的組織集団の活動
表-2 構成機能によるアンケートの回答項目の分類

\begin{tabular}{|c|c|c|}
\hline 分類項目 & 湅分類 & 回答開倠事菜 \\
\hline \multirow{8}{*}{ 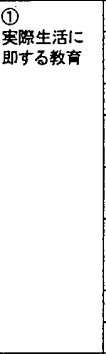 } & 子音七 & 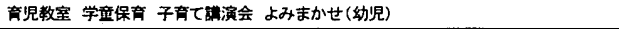 \\
\hline & 料理 & 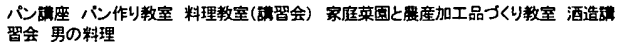 \\
\hline & コンピュータ & インターネット教室 パソコン教室 パコン大会 ワープロ教室 \\
\hline & 实用 & 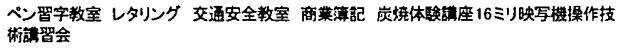 \\
\hline & 家庭とくらし & 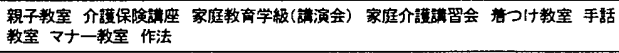 \\
\hline & 地域 & 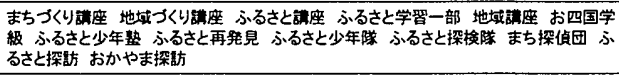 \\
\hline & 瓄境 & 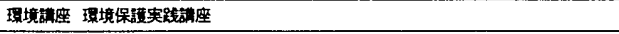 \\
\hline & 人椎 & 人権語座 同和教育 \\
\hline \multirow{5}{*}{ 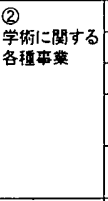 } & 文学 & 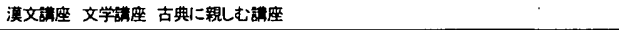 \\
\hline & 伝統文学 & 川披教室 俳句教室 句楽会 菬吟短歌 万葉策 \\
\hline & 浯学 & 各種外国語教室 カタカナ眖 英会話教室 \\
\hline & 歴史 & 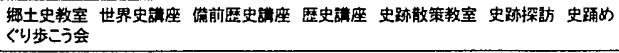 \\
\hline & 自然 & 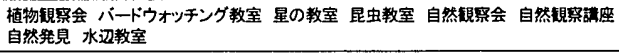 \\
\hline \multirow{13}{*}{ 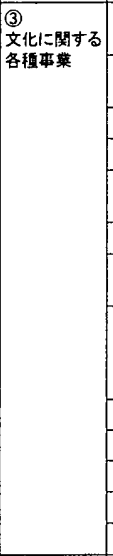 } & 公演 & 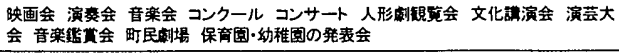 \\
\hline & 展示 & 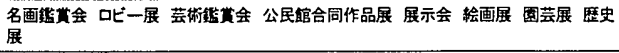 \\
\hline & 生け花 & アートフラフー生け花教室 フラフーアレンジメントフラフーバスケット教室 \\
\hline & 園芸 & 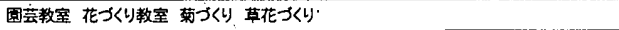 \\
\hline & 桧画 & 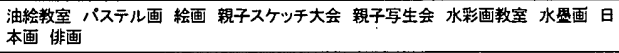 \\
\hline & 音澘 & キターコーラス教室 ハモモ二カ教室 ピアノ教室 唱歌を楼しむ会 \\
\hline & 手芸 & 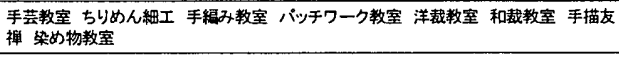 \\
\hline & 工芸·工作 & 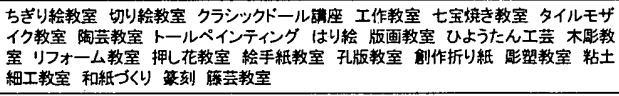 \\
\hline & 文化財 & 親子女化財 \\
\hline & 写真 & 写真教彥 \\
\hline & 伝较普楽 & 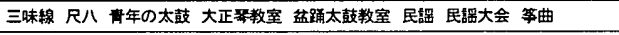 \\
\hline & 伝较芸能 & 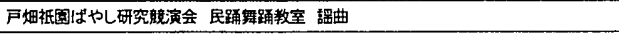 \\
\hline & 伝綪文化 & 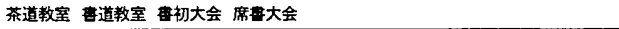 \\
\hline \multirow[t]{2}{*}{\begin{tabular}{|l|} 
(4) \\
体育に関する \\
各種策会
\end{tabular}} & 体亮大会 & 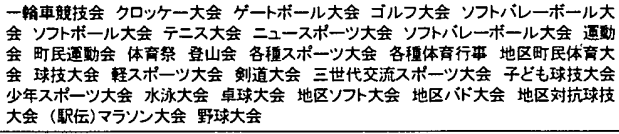 \\
\hline & 体育教室 & 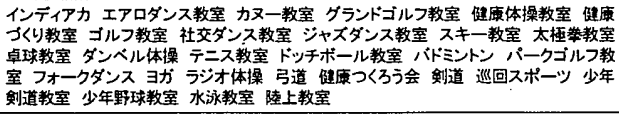 \\
\hline \multirow[t]{2}{*}{$\begin{array}{l}\text { (5) } \\
\text { レクリエーション } \\
\text { に關するす菓会 }\end{array}$} & 㜏菜 & 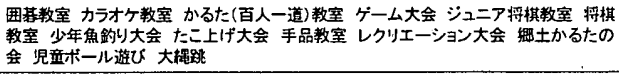 \\
\hline & 野外活動 & 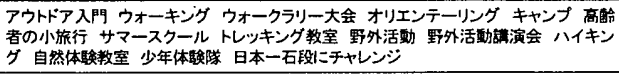 \\
\hline \multirow{2}{*}{ 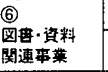 } & 图曹 & 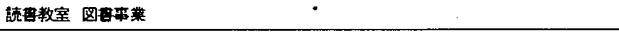 \\
\hline & 情報提伴 & 館報 情報提伴 \\
\hline 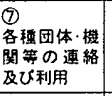 & 団体活動 & 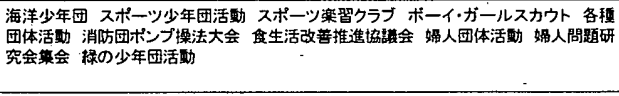 \\
\hline \multirow{5}{*}{$\begin{array}{l}8 \\
\text { 住民の集会 }\end{array}$} & 冠婚䰜祭 & 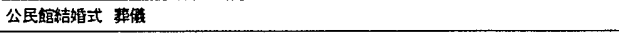 \\
\hline & 祭少 & 祭りこども祭り 公民館祭り 酒まつり 納涼盆踊り大全 \\
\hline & 行平 & 敬老記念行 成人粑念行 バザー 文化祭 餅つき \\
\hline & 交流 & 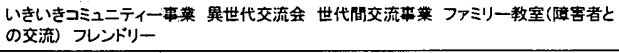 \\
\hline & 住民㮔会 & 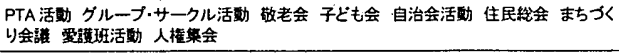 \\
\hline \multirow{2}{*}{$\begin{array}{l}\text { (9) } \\
\text { その地の } \\
\text { 公共的利用 } \\
\end{array}$} & 公共利用 & 各種换定 災害辝新所 投賈所 \\
\hline & 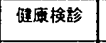 & 3才児换彭 予防接理 \\
\hline $\begin{array}{l}\text { (11) } \\
\text { 相談 } \\
\end{array}$ & 相談 & カウンセリング 相瑓相談 生活相談 \\
\hline 福祉 & ボランティア & 楅社活動 防犯 ボランティア活動 ボランティア諈座 清揜奉仕活動 \\
\hline \multirow[t]{3}{*}{ (a) } & 浬·学极 & 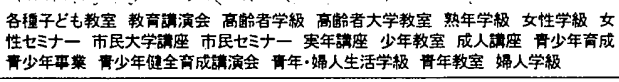 \\
\hline & 研佟会 & 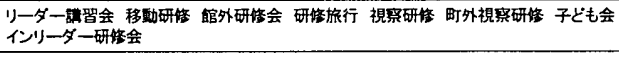 \\
\hline & 铝習 & 各種的盟会 \\
\hline (1) & 事莱形態 & 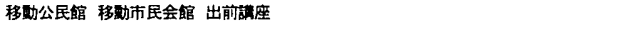 \\
\hline
\end{tabular}


は\{8住民の集会\}に分類する。\{8住民の集会\} は，住民の交流 を目的とする行事，まつりと冠婚葬祭など住民生活に関わる集会で ある。\{(9)その他の公共的利用\} は，行政または地方自治体などの 公共的利用である。

\{110相談\}は，法令等にはあげられていないが赛態としてみられる ことから各種相談機能を抽出し分類する。

\{11福祉 $\}$ は, 具体的事例は少ないが社会教育法で公民館の設置目 的の 1 つにあげられていることから, ボランティア活動を中心とす る奉仕活動に関寸る分類項目として用いる。

\{@\}は，具体的な開催事業の内容が判断できない回答であるが， 目的行為または対象を示寸回答項目であり，その目的行為が学習， 教育と判断できるため, 学習, 教育に関わるすべての分類項目 (1)(2) (3)に重複集計才る。'各種講座', ‘各種講習会’, ‘高澮者学級’な どがその範疇に即する。

\{(b) は, ‘移動公民館’, ‘出前講座’など, 開催事業の事業形態 を示す回答であるため, 公民館主催事業に関わるすべての分類項目 (1)(2)(3)(4)(5)(6)に重複集計する。

以上の分類項目(1)〜(11)は, 「教育, 文化, 集会, 福祉」, (a), (b)は, 「事業形態」という概念で分類したもので, これらの項目は公民館 の目的を達成するための手段として設定された ‘構成機能’に相当 オる。

なお，表-2 の細分類 46 項目はアンケートに出現した事業を内容 別に分類したものである。

\section{4-2 全国の公民館における開催事業の傾向}

前項で分類整理した分類項目をもとにアンケートのカテゴリー 別の全国回答率を分類項目ごとに図-1に示す。図-1 は 1 事例のみ の回答項目を除いた回答率である*19。

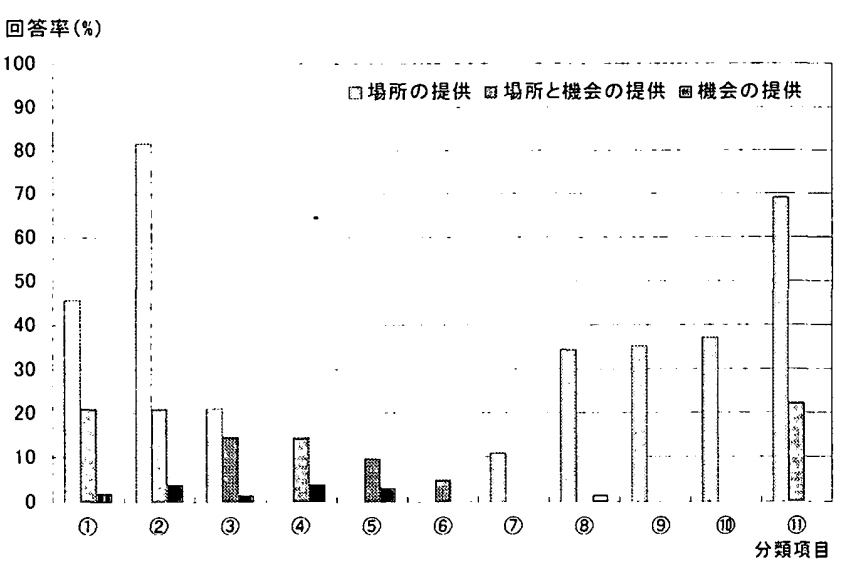

注)グラフの分類項目軸のまる番号は表-2の分類項目を示す。 (1)实際生活に即する教育 (2)学術に関する各種事菜 (3)文化に関する各種策革 (4)体育

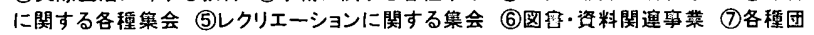

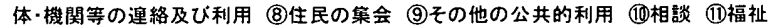

\section{图-1 分類項目別全国回答率}

図-1 から，公民館の開催事業の全国傾向をみると，以下のように 整理できる。

外部組織の開催事業について回答を求めた[場所の提供]のカテ
ゴリーには，\{(1)実際生活に即する教育\}，\{(2)学術に関する各種事 業\}，\{(3)文化に関する络種事業\}，\{(7)各種団体·機関等の連絡及び 利用\}，\{8住民の集会\}，\{(9)その他の公共的利用\}，\{(10相談\}，\{(11) 福祉）の分類項目の事菜が行われている。

公民館で行う公民館注催事業について回答を求めた[場所と機会 の提供了のカテゴリーには, (1)実際生活に即する教育\}, \{(2)学術に 関する各種事業\}, \{(3)次化に関する各種事業\}, \{(4)体育に関する各 種集会\}，\{(5)レクリエーションに関する集会\}，\{(6)図書·資料関連事 業\}，\{(11福祉\} の分類項目の事業が行われている。

公民館外で行う公民館主催事業について回答を求めた[機会の提 供]のカテゴリーには, \{(1)実際生活に即する教育\}, \{(2)学術に関す る各種事業\}，\{(3)文化に関する各種事業\}，\{(4)体育に関する各種集 会\}, \{(5)レクリエーションに関する集会\}，\{8住民の集会\}の分類 項目の事業が行われている。

その中から，(1)(2)(3)(11)分類項目はその事業主体が公民館と外部 組織とともに行われている事業であるが，(4)(5)(6)(7)(8)(9)(10)分類項 目は公民館の主催事業に関わる項目 (4)(5)(6) と外部組織の開催事 業に関わる項目（78(8)(10) にはっきり区分されている。つまり， 体育, レクリエーション, 図書関連事業に各公民館運営の独自性, 寸なわち ‘選択的多様性*3’がみられることを示している。

カテゴリー別回答率をみると [場所の提供]と [場所と機会の提 供］の回答率が高く、［機会の提供］の回答率が全般的に低いこと から，公民館で行う公狼館の主催事業とともに外部組織の開催事業 が公民館の主な事業として位置づけられる。また，[場所と機会の 提供]より [場所の提供]の回答率が相対的に高いことから，外部組 織の貸し館的な利用が公民館の主催事業より活発であると言える。 しかし,アンケート調㳫から得られた 1 事例のみの開催事業を除い た開催事業の数は，[㙃所と機会の提供］の 82 種類にくらべ，[場 所の提供]が 30 種類で泫ることと，その内容が ‘住民総会”， ‘災害 避難所’，“投票所’など特定用途で利用されていることから， [場 所の提供]は特定用途の事業に限られていると言える。

以上の分析結果から，公民館の開催事業は，公民館が企画し行う 公民館主催事業と貸し館的に利用している外部組織の主催事業に 分けられ，その事業の内容も学習, 教育関連項目 (1)(2)(3) 以外は 事業主体によって異なることがわかる。

[場所の提供]において (8)〜迆分類項目が相対的に高い回答率を みせていることから，集会機能と相談・福祉関連機能も公民館の主 な機能として位置づけられる。これらは，公民館の普遍的な機能と して社会教育機能と住民の集会機能を示した筆者らの既往の研究*6 結果と一致する点があり，社会教育施設として法律的に位置づけら れている公民館が，住民の集会と相談·福祉関連機能に関しても役 割を果たしていることを示すものである。

\section{4-3 地方別公民館の開催事業の特㮹}

公民館の開催事業の地方別傾向を把握するために, 前項で得られ たカテゴリーごとの分傾項目別回答率を地方別に再集計し, 地方別 回答率を求める。

求められた地方別開催事業の回答率を地方間の比較分析を行う ために，分類項目別に基準化し，その結果を図-2に示す。 


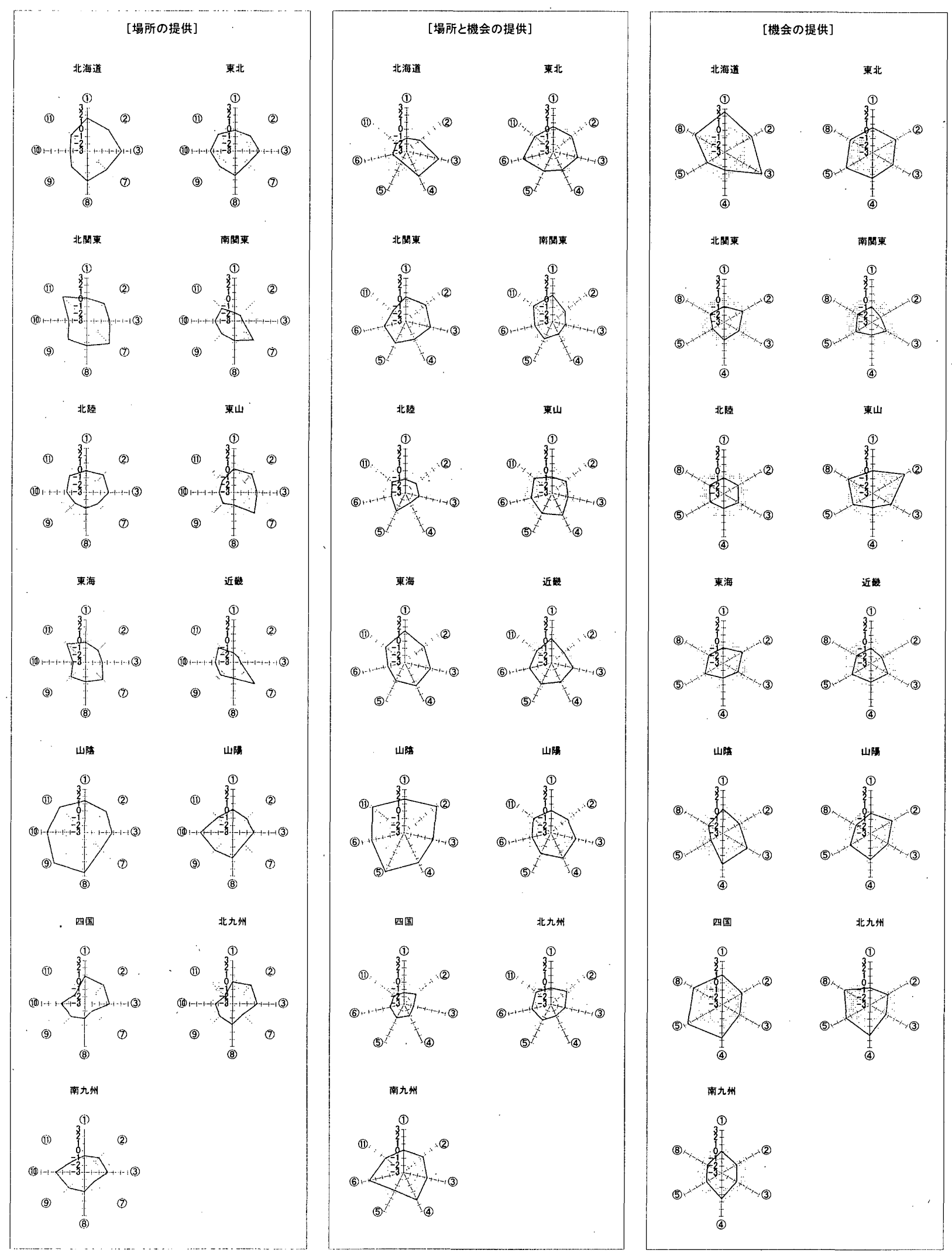

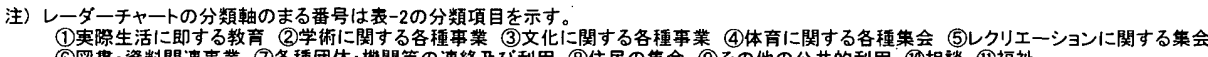

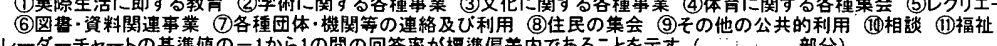

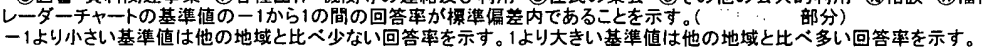

図-2 公民館の役割の分類項目別地域別レーダーチャート 
図-2から，標準偏差上下限内（基準值－1から１の間）に回答率 があらわれている地方は，その該当分類項目に関わる事業が全国平 均水準であって，標準偏差上下限外（基準值一 1 以下， 1 以上）の 分類項目に関しては，地方の特性として解釈できる。カテゴリー別 においても，地方別においても図-2 のレーダーチャートの様態はさ まざまで，公民館の多様性を示している。

地方別に 3 つのカテゴリーのレーダーチャートを比較し，カテゴ リーごとに様態が異なっている地方とその内容を以下のようにま とめる。

北海道地方は, [場所の提供]と［機会の提供]のカテゴリーの開 催事業が [場所と機会の提供]のカテゴリーの開催事業より回答事 例数が多いことがわかる。すなわち, 貸し館的利用と館外活動が中 心であると言える。

東海, 近畿, 南九州地方は, [場所と機会の提供]のカテゴリーの 開催事業の回答事例数が多く，館内活動が中心であると言える。

山陰地方は，[場所の提供］と［場所と機会の提供]のカテゴリー の開催事業の回答事例数が多く, 貸し館的利用と館内活動が中心で あると言える。

四国地方は，[機会の提供]のカテゴリーの開催事業の回答事例数 が多く，館外活動が中心であると言える。

次に, 図-2 から基準值が標準偏差の上限以上と下限以下の地方と 分類項目を抽出し，表-3にまとめる。

表-3で, 一で表示される地方の分類項目は他地方に比心゙, 回答事 例数が少なく，十で表示される地方の分類項目は他地方に比べ, 回 答事例数が多いことを示している。

表-3 から，開催事業の回答率の差があらわれた地方は，全 13 地 方の中, [場所の提供]のカテゴリーには 10 地方，[場所と機会の提 供]のカテゴリーには 9 地方, [機会の提供] のカテゴリーには 9 地 方がある。すなわち，70\%ぐらいの地方でその開催事業に回答事例 数が異なっている。これは，地方別に公民館の様態が異なることを あらわしている。

また，地域差の大きい地域として基準值が \pm 2 を超える 11 個の 特別例（表-3の 表示部分）に該当する 5 地方を取り上げ，そ の具体的な事業内容を検討寸ると以下のようである。

[場所の提供]のカテゴリーにおいては，近畿地方の \{(2)学術に関 する各種事業\} 項目の回答事例数が少ない。ここでは, ‘各種講習 会”の回答率が $55.6 \%$ で, 全国平均の $82.6 \%$ より低い。山陰地方 では \{8住民の集会\}項目の ‘住民総会”，“祭り’，“敬老会”，“敬 老記念行事”，何その他の公共的利用\}項目の '災害避難所’，“投 票所’，“予防接種”，\{10相談\}項目の ‘健康相談”項目が全国平均 とくらべ2〜 倍ぐらい高い回答率をみせている。

[場所と機会の提供]のカテゴリーにおいては，山陰地方の \{(2)学 術に関する各種事業\}項目の ‘教育講演会’, “鄉土史教室”, ‘川柳 教室”と事業形態としての“移動公民館’， \{(5)レクリエーションに 関する集会）項目の ‘囲碁教室'，“将棋教室’，“カラオケ教室', 事業形態としての“移動公民館”, \{11福祉 \} 項目の ‘ボランティア 講座’ 項目が全国平均とくらべ 2〜5 倍ぐらい高い回答率をみせて いる。

[機会の提供]のカテゴリーにおいては，北海道地方の\{1実際生

\section{表-3 公民館機能の地方別特性}

\begin{tabular}{|c|c|c|c|c|c|c|c|c|c|c|c|c|c|}
\hline \multicolumn{14}{|c|}{ 㘯所の提供 } \\
\hline 地方 & 北海道 & 東北 & 北関東 & 南関果 & 北陸 & 東山 & 東海 & 近焦 & 山陸 & 山禹 & 四国 & 北九州 & 南九州 \\
\hline (1) & + & & & - & & & & - & + & & & & \\
\hline (2) & + & & & - & & & & $\sqrt{3}$ & + & & & & \\
\hline (3) & + & & & - & & & & - & & & & & \\
\hline (4) & & $\%$ & 13 & W & & & 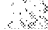 & $\therefore$ & . & 4 & 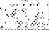 & 6 & \\
\hline (5) & 8 & 88 & \% & 10 & 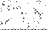 & 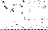 & m & 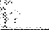 & 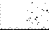 & 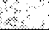 & 3 & s & \\
\hline (6) & 3 & 3 & S & 13 & & 3 & m & 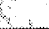 & 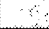 & $x_{2}$ & $+\infty$ & 8 & \\
\hline (7) & & & + & & & + & & + & - & & - & & - \\
\hline (8) & + & & & & & - & & & 8 & & & & \\
\hline (9) & & & & & & & & & 12.2 & & & & \\
\hline (11) & & & & & & & - & & 10 & & & & \\
\hline (11) & & & + & & & & & & + & & - & - & \\
\hline
\end{tabular}

\begin{tabular}{|c|c|c|c|c|c|c|c|c|c|c|c|c|c|}
\hline \multicolumn{14}{|c|}{ 㙁所之機会の提阱 } \\
\hline 地方 & 北海道 & 東北 & 北関東 & 南成東 & 北陸 & 東山 & 東海 & 近数 & . 山陆 & 山陆 & 四国 & 北九州 & 南九州 \\
\hline (1) & - & & & & - & & + & & + & & - & & \\
\hline (2) & & & & & - & & & & 12 & & & & \\
\hline (3) & + & & & - & & & & & + & & - & & \\
\hline (4) & & & & - & - & & & & + & & - & - & + \\
\hline (5) & - & & & & & & & & 8 & & & & \\
\hline (6) & - & + & & & - & & & & + & & - & & + \\
\hline$(7)$ & 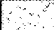 & $x^{2}$ & 18 & (a) & 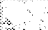 & $x^{2}$ & 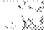 & 3 & 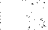 & $\%$ & $x^{2}$ & . & \\
\hline (8) & 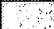 & 8 & & (1) & 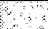 & 8 & 3 & 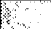 & 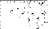 & $\sqrt{4}$ & . & .8 & \\
\hline (9) & 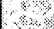 & 2 & (j) & Wor & $2 \%$ & $7 x$ & 48 & m: & 4 & 12 & 10 & m & \\
\hline (ii) & 25 & r. & Then & W"X & 10 & (x) & (1) & ma & 7 & W6! & mon & \% & 8 \\
\hline (11) & - & & & & & & & & खण? & & - & & \\
\hline
\end{tabular}

\begin{tabular}{|c|c|c|c|c|c|c|c|c|c|c|c|c|c|}
\hline \multicolumn{14}{|c|}{ 機会の提供 } \\
\hline 地方 & 北海道 & 東北 & 北関東 & 南臂東 & 北陸 & 東山 & 東海 & 近糙 & 山陸 & 山睡 & 四国 & 北九州 & 南九州 \\
\hline (1) & 10 & & & & & & & & & & + & & \\
\hline (2) & + & & & - & & 4 & & - & & & & & \\
\hline (3) & 4 & & & & & & & & & & & & \\
\hline (4) & & & & - & & - & & & + & & + & + & \\
\hline (5) & & + & - & & & & & & - & & 27 & & \\
\hline (6) & & 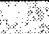 & 8. & 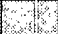 & $\therefore$ & & 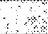 & & & $\therefore$ & 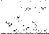 & 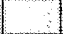 & \\
\hline$(8)$ & 8 & 3 & 15 & 10 & 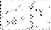 & 4. & 98 & $\therefore$ & $\because$ & a & 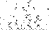 & 8 & \\
\hline (8) & + & & & & & & & & & & + & + & \\
\hline (9) & 6 & r. & (x) & p & 6 & 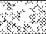 & 8 & 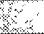 & 6 & Whe & Whe & 1 & \\
\hline 0 & 3 & & 获 & 4 & 8 & 56 & 4 & 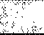 & 7 & 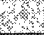 & 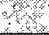 & 3 & \\
\hline (1) & 8 & 18 & 17 & 18 & 4 & 6 & 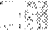 & 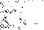 & & 8 & 69 & 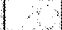 & \\
\hline
\end{tabular}

注）表の項目のまる番号は表-2 の分類項目を示す。

(1)実際生活に即する教育 (8)学術に関する各理事業 (3)文化に関する各種事業 (4)体有 に関する各種集会 (5)レクリ:エーションに関する集会 6)図夆·資料関連事菜 (7)各種団 体・機関等の連絡及び利用 (8)住民の集会 (9)その他の公共的利用 (10)相談 (11)福祉 十は箱準偏差上限以上, 一は樏準偏差下限以下を示す。

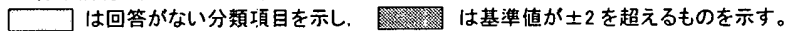

活に即する教育) 項目の ‘地域講座”，“館外研修会”，‘パソコン教 室’，“高齢者学級’，“市民大学講座’， (3)文化に関する各種事業\} 項目の ‘館外研修会’, ‘親子写生会', ‘高路者学級’, ‘市民大学講 座”が，東山地方の \{(2)学術に関する各種事業\}項目の“植物観察 会’，“星の教室”，“館外研修会’，“歴史講座”が，四国地方の (5) レクリエーションに関らる集会\}項目の ‘野外活動講演会’, ‘ゲー ム大会’, ‘少年釣り大会’，“八イキング’, ‘キャンプ”が高い回答 率をみせている。

以上で考察した地域差の大きい地方の開催事業は，その地域の公 
民館の特性としてみられるものである。いずれも地域の特性を反映 したものと考えられる。

\section{5. 公民館の役割に関する戝員の意識からみる公民館の機能}

公民館の役割に関する職員の意識に関するアンケート調査の結果 を，「教育」，「自治」，「福祉」の 3 つの調查項目ごとに重要度が第 1 位と答えた事例別に集計し，全国回答率と地方別回答率を求め，図 -3 に示す。

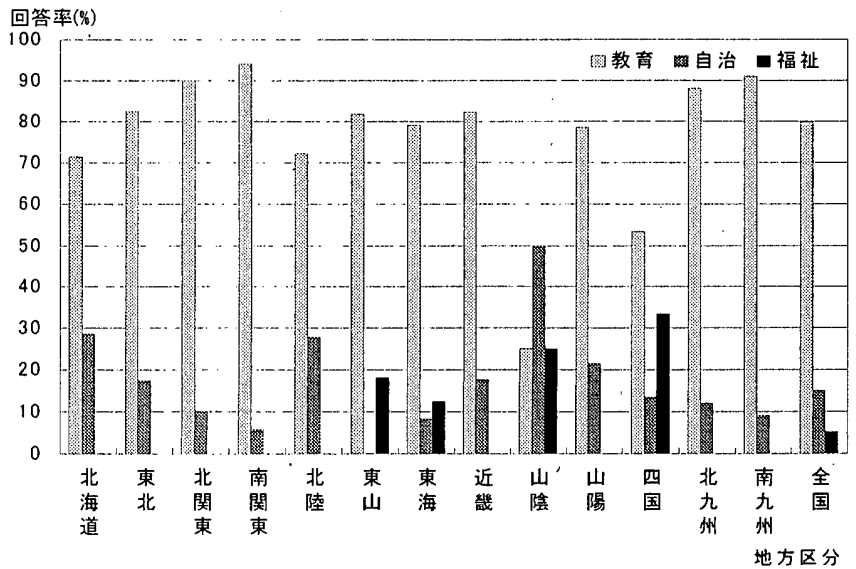

図-3 公民館役割に関する職員の意識の地方差

図-3 から，公民館の役割に関する職員の意識としては「教育」機 能が公民館の普遍的機能として認識されていることがわかる

(79.8\%)。しかし，「自治」(15.0\%)，「福祉」(5.2\%) の順に回 答がみ、られることから，公民館は社会教育施設としての「教育」機 能だけではなく，公民館の形成過程でみられる地域の総合的施設と しての役割を果たしてきた「自治」と「福祉」機能もいまだに残さ れていることがわかる。特に，「福祉」に関して回答がみられる， 四国 $(33.3 \%)$ ，山隍 $(25.0 \%)$ ，東山 $(18.1 \%)$ ，東海 $(12.5 \%)$ の 4 つの地域は，地域の特徴としてあげられる。

また，公民館の役割に関する職員の意識も地方ごとに異なること がわかる。公民館の役割に関する職員の意識の地方別回答率を調查 項目ごとに基集化を行い，標淮偏差上下限外の地方を抽出し表 -4 に示す。

\section{表-4 公民館の役割に関する職員の意識の地方別特性}

\begin{tabular}{|c|c|c|c|c|c|c|c|c|c|c|c|c|c|}
\hline 地方 & 北海道 & 東北 & 北関東 & 南関東 & 北陸 & 東山 & 東海 & 近喽 & 山隘 & 山陆 & 四国 & 北九州 & 南九州 \\
\hline 教育 & & & & & & & & & -3 & & - & & \\
\hline 自治 & & & & & & - & & & t & & & & \\
\hline 福祉 & & & & & & & & & + & & + & & \\
\hline
\end{tabular}

注）十は摽準偏差上限以上, 一は椤準偏差下限以下を示す。 ①基準値が士2 を超えるものを示す。

表-4 から, 公民館の役割に関寸る職員の意識の差があらわれた地 方は，東山，山陰，四国地方である。この3つの地方の調査項目ご
との回答率を図-3 から求めると以下のようである。

東山地方は，「自治」がなく，山陰地方は，「教育」が全国平均回 答率と比べて $30 \%$ ぐらい低く，「自治」と「福祉」の回答率が 3 倍

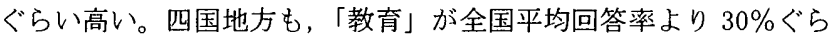
い低く「福祉」が 7 倍ぐらい高い。

以上のことから，公民館の職員，寸なわち施設管理者側が認識し ている公民館像として, 社会教育施設と地域の総合的施設があり, その $2 つ の$ 施設像の認識は地域によって異なっていることが検証で きた。

\section{6. 公民館の施設機能的特性と地域施設の再編に係る施設計画要素}

公民館の開催事業の実態を検討した第 4 章から, 公民館の主催事 業とともに，各種団体·機関等の利用，住民の集会，その他の公共 的利用, 相談, 福祉関連事業の事業形態にみられる貸し館的な利用 も主な事業形態であることがわかった。また，公民館整備にあたっ て，当該公民館に備えるべき個別的機能を設定するとき，以下の要 素が計画指針となることがわかった。

1）活動形態

館内活動·館外活動

2) 事業主体と活動場所

場所の提供·機会の提供·場所と機会の提供

3) 構成機能

実際生活に即する教育・学術に関する各種事業・文化に関する各 種事業・レクレーションに関する集会·住民の集会·設置基準以外 の公共的利用·相談·福祉

公民館に関する職員の意識を検討した第 5 章から，社会教育施設 としての教育機能は勿論, 地域の総合的施設としての自治, 福祉機 能も公民館の機能として認知されていることがわかった。

さらに, 公民館の開催事業と公民館に関する職員の意識はともに 地方別に差があり，多様に展開していることが検証できた。

以上の分析結果は，公民館の基本的な性格と機能に関する公民館 の初期創設期からの論争と通じる部分がある。

公民館論争は，公民館の機能論と制度論，地域振興の運動論と社 会教育の専門的機関論などが中心論題であって，地域総合的機能論 と社会教育専門的機関論は公民館論議の基礎となっている*12。公民 館論争の 2 つの大きな問題は, 本稿の公民館の実態分析から得られ た公民館の特性と一致している。すなわち，議論された公民館の基 本的な性格に関する課題は, 実態としてもいまだに存在している。

そこで，公民館の実態と理論から，公民館の基本的な性格は「社 会教育施設」と「地域の総合的中心施設」とすることができる。ま た，公民館の施設計画のために検討するべき計画要素として，社会 教育施設としての ‘社会教育”機能, 地域の中心施設としての ‘地 域自治”，“地域福祉”機能があげられる。

今後の地域施設を再構築するためには，まず，公民館の基本的性 格を認識し，公民館における計画目標的要素である‘社会教育”, ‘地 域自治”，“地域福祉”の課題をどのようにとらえ，再編する地域施 設群のなかで展開していくかが重要であると考える。 


\section{7. まとめ}

1）全国を対象とした公民館の実態に関するアンケート調査の分析 結果から，以下のような公民館の事業内容の多様性と地域的多様性 が検証できた。

公民館の事業内容の多様性としては，304 種類の開催事業の多様 な名称が得られ，その中で当該 1 事例のみの事業，すなわち個別的 事業が約半分であることがわかった（表-1）。

地域別にみても，図-2のようにさまざまな様態であることがわか った。

2）施設の目的達成のための手段として設定される ‘構成機能’に 相当する 11 分類項目が提示できた。この分類指標を用いて全国の 公民館でみられる事業が分類できた（表-2）。

“構成機能” は施設計画における目標設定の重要な計画要素である とともに，施設の存在価值を解釈·評価する基準として，今後の地 域施設再編に関わる検討に応用できる指標であることがわかった。 3）公民館の開催事業を事業主体と事業の行う場所により，[場所の 提供 - 外部組織の開催事業], [場所と機会の提供 - 公民館で行う公 民館主催事業]，[機会の提供 - 公民館以外で行う公民館主催事業] の3つのカテゴリーに分けて検討することが有効であることが検証 できた。

4）公民館の開催事業と公民館に対する職員の意識の分析から，公 民館の施設特性は, 社会教育の専門施設としての機能と地域の生活 全般にわたる総合的施設としての機能があげられ，その施設計画的 要素として, 社会教育, 地方自治, 地方福祉があげられることが検 証できた。

[注]

*1 浌野平八『地域集会施設の計画と設計』理工学社 $(1995)$, pp. 30 31 参 照。

*2千葉県公民館連結協議会編『千葉県公民館史』弘文社 (1985) に上ると。 公民館の源流となる施設は，地域住民の総合的文化センターとしての機 能を果たしていて, 初期公民館は, 戦後復興のための町村の産業·文化· 教育活動の拠点施設であったと述べている。また，1945 年の公民館構相 では，公民館の機能として，社会教育，自治振與，社会娛楽，産業振興， 青年育成などをあげている。

*3 日本社会教育学会編『現代公民館の創造 ; 公民館 50 年の歩みと展望』東 洋館出版社 (1999)， p. 334 参照。

*4 正式名称は，'生涯学習の振興のための推進体制等の整備に関する法律' である。

*5 朝比奈 博, 工藤日出夫編著『未来型公民館八の $7 \supset 0$ 条件』日常出版 株式会社（2000）によると，転換期に打ける現代的課題（地域社会が抱 えている課題）を公民館が的確にとらえ，社会的に潜在しているニーズ 八対応寸る学習の必要性を述べている。

長澤成次編著『公民館で学ぶ; 自分づくりとまちづくり』国土社 (1998) によると，公民館制度の変化にしたがって，21 世紀を狙う公民館の課題 について述べている。

小林文人編著『公民館の再発見；その新しい実践』国土社（1988）に上 ると，公民館が関わっている政策等の改革により，公民館制度の見直し と公民館が果たしてきた独自の役割を再発見して，その展望を明らかに 寸ることが必要であると述べている。

*6 金 潤煥, 浅野平八，広田直行「活動状況からみた現在の公民館の役割」 日本大学生産工学部 第 34 回学術講演会 (2001), pp. 5 8

*7 日本社会教育学会編，前揭書 (注 $* 3)$, p. 13 参照。

*8 金 润煥, 浅野平八, 広田直行「思考展開少らみる公民館の機能分析」 日本建築学会計画系論文集 第 556 号 (2002 年 6 月), pp. 153 160で 施設の機能を体系的に分析する方法として，思考展開の流れにしたがっ て施設機能を段階別に示した。施設計画における思考は, “要求機能” 一 '構成機能” - ‘要素機能’ に展開寸る (p.155 0)図 $-2,15.156$ の図 -3 参照)。
*9 優良公民館は，都道庥県教育委員会から推薦のあった被表彰候補公民館 について，優良公民館審查委員会（学識経験者，公民館関係代表者等 8 名で構成）において蕃查の上，決定し，文部大臣が表彰する。その蕃査 の基準としては, 公民館のうち, 特に事業内容・方法等に工夫をこらし 地域住民の学習活動に大きく貢献していることを前提としている。 優良公民館表彰は，1948 年度から実施され，2001年度までに表彰され た優良公民館は $1 ， 237$ 館である。しかし，重複受賞している公民館も多 いだめ, 実際受賞公民:館数は統計値より少ない。

*10 全国の優良公民館の受、賞記録が残っている資料として，全国公民館連合 会発行の『全国公民館名簿』（1965）、『全国公民館名鑑』（1979，1991） を参考にしたため, 調査時点での最新版である 1991 年の全国公民館名 鑑に載っている受賞館までを調查対象とした。

*11 一般的には回収率と回答率は全質問アンケート数に対寸る応答アンケー 卜数の比率を意味し，同じょうに使われているが，本稿においては，回 収率がその意味で，回答率は回収された応答アンケートの中で1つの犋 問項目に対する回答事·例の比率を示すこととする。 地方別回収率と回収䒠:数は以下の上うである。

全国 40.2\% (223/555)，北海道 41.2\% (7/17)，東北 $42.3 \%(41 / 97)$ ，北 関東 $34.5 \%(10 / 29)$, 南関東 $55.9 \%(19 / 34)$, 北陸 $29.0 \%(18 / 62)$, 東 山 $52.4 \%(11 / 21)$, 東海 $44.6 \%(25 / 56)$, 近畿 $40.0 \%(18 / 45)$, 山陰 $30.8 \%(4 / 13)$ ，山陽 $31.3 \%(15 / 48)$ ，四国 $35.7 \%(15 / 42)$ ，北九州 $45.2 \%$ (28/62), 南九州 $41.4 \%(12 / 29)$

*12 日本社会教育学会編，前掲書（注*3），pp. 18２4 参照。

*13 日本社会教育学会編, 前掲書（注*3)，pp. 281〜285によると，社会教育 法の制定は公民館が教育機関であることを明確にしたため, 社会福祉と 社会教育を総合化する意識が生まれたが，自治公民館論からみると，地 域の不可欠な諸機能をもつ公民館の課題として“社会福祉的協同関保” がとりあげられている。

*14 文部科学省の社会教育調查の学級・講座の分類項目は，教盖の向上(趣味 活動を含む)，体育・レ・クリエーション，家庭教育·家庭生活，職業知識· 技術の向上，市民意識: 社会連帯意識，その他に分類されていて，市町 村の社会教育統計の 1 例として船橋市の場合をみると，学級·講座，集 会活動，その他に分類している。

*15 地理的環境が含まれていると考えられる公民館の多様性を分析するため には，道都府県段位よりは大きく、気候や地理的条件を地域区分の指標 にしている農林水産省の地域区分が適合であると判断した。ただし，山 陰地方は母集団が少なく詳しく再検討する必要がある。

農林水産省の全国の㖘業地域区分は，北海道（北海道），東北(青森県， 秋田県, 山形県, 岩手県, 宮城県, 福島県), 北関東(栃木県, 群馬県, 茨城県)，南関東(神奈:川県，埼玉県，東京，千葉県），北陸(新潟県，富 山県, 石川県, 福井県), 東山(長野県, 山梨県), 東海 (静岡県, 愛知県, 岐阜県, 三重県)，近機(滋賀県，京都府，奈良県，和歌山県，大阪府， 兵庫県), 山陰(鳥取県, 島根県), 山陽（岡山県，広島県，山口県），四 国 (徳島県, 香川県, 受媛県, 高知県), 北九州 (福岡県, 传賀県, 長崎 県, 大分県, 熊本県), 南九州 (宫崎県, 鹿览島県), 沖縄 (神縄県) の 14 地方である。

*16 神縄県には優良公民館として文部大臣表彰を受けた事例がないため, 本 稿では沖䋥がなく 13 地方になる。

*17 ここで言う基隻化とは，平均と標準偏差で決定される分布を対象に標準 化変量を求める方法で，その計算式は $\mathrm{Z}=(\mathrm{X}-\mu) / \sigma(\mathrm{Z}$ : 標準化変量, $X$ : 対象となる数値, $\mu$ : 算術平均, $\sigma$ : 標準偏差)である。標準化と も言う。

*18 金 潤焕, 浅野平八, 広田直行, 前揭論文 (注*8), pp. 155 156 で, 設 計に扩思考展開の,過程を用いた公民館の機能分析の方法として，実 際の使わ北方の分析から得られる実態機能分析と施設の計画段階で設定 される設定機能分析を示した。公民館の設定機能においては, 社会教育 法等に定められていることから，関連法令が設定機能の判断基隻となる。 特に目的達成のための，事業内容で示す ‘構成機能” の段階は，社会教育 法第 20,22 条と公民館の設置及び運営に関する基準の第 3 条の 2,3 項 に示されている。

*19 アンケート調查から得られた 1 事例のみの開催事業は回答率の偏差组を 小さくするために除いて集計した。

（2002年12月10日原稿受理，2003年 4 月 22 日採用決定） 